\title{
Experimental Contribution to the Dithranol-Brown Problem
}

\author{
W. Wiegrebe ${ }^{1}$, E. Plumier ${ }^{1}$, K. K. Mayer ${ }^{1}$, U. Runne ${ }^{2}$, W. Schultz-Amling ${ }^{2}$, J. Rosmarinowski ${ }^{3}$, \\ G. J. Safar ${ }^{3}$, and K. D. Kubka ${ }^{3}$ \\ 1 Faculty of Chemistry and Pharmacy of the University, PO Box 397, D-8400 Regensburg, Federal Republic of Germany \\ ${ }^{2}$ Department of Dermatology and Venerology (Division I), J. W. Goethe University, Frankfurt am Main, \\ Federal Republic of Germany \\ 3 Institute for Biophysics, J. W. Goethe University, Frankfurt am Main, Federal Republic of Germany
}

Key words: Dithranol - Metabolization in epidermis - Dithranol-Brown - Copper

Dithranol is well known to dermatologists: during antipsoriatic therapy with dithranol, a brownish staining frequently occurs in the lesions as well as the surrounding non-involved skin, and there have been various efforts [5] to eliminate or to diminish this side effect. The present study is concerned with dithranol brown located in the brown psoriatic scales obtained from patients undergoing dithranol therapy (dithranol with $2 \%$ salicylic acid in white soft paraffin).

Microscopic examination showed that dithranol brown is deposited in the form of well-defined brownish particles in the stratum corneum. These particles were isolated using a micromanipulator and introduced into a $311 \mathrm{~A}$ mass spectrometer via a heated inlet system $\left(90^{\circ} \mathrm{C}, 120^{\circ} \mathrm{C}\right)$. High resolution revealed the presence of hydrocarbons $\left[\mathrm{C}_{18} \mathrm{H}_{36}, \mathrm{C}_{28} \mathrm{H}_{5} \mathrm{~A}\right.$, $\mathrm{C}_{27} \mathrm{H}_{44}$ (cholestadiene)] and an oxygenated steroid $\mathrm{C}_{27} \mathrm{H}_{46} \mathrm{O}$ (cholestenol or cholestanone). When the inlet system of a $\mathrm{CH} 5$ mass spectrometer was heated to $450^{\circ} \mathrm{C}$, we obtained a very weak signal at $\mathrm{m} / \mathrm{z}=446$ from a dimethylsulfoxide (DMSO) extract of brown scales, which might be attributable to tetrahydroxyhelianthrone [2]; under these conditions, however, the formation of artifacts cannot be excluded.

The proteolytic degradation of brown scales using Pronase followed by $\mathrm{CHCl}_{3}$ extraction revealed the molecular ions of dithranol, chrysazine and 1,8, $1^{\prime}, 8^{\prime}$ tetrahydroxybisanthrone $(\mathrm{m} / \mathrm{z}=450 ;<1 \%)$, and the corresponding fragment ions (Fig. 1).

The excitation of a single brown particle to an ionized state under microscopic control using a

Offprint request to: Dr. W. Wiegrebe (address see above)

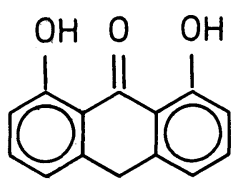

1

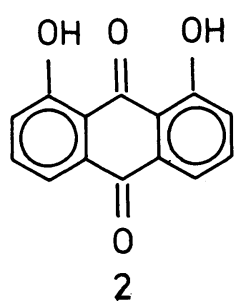<smiles></smiles>

Fig. 1. Formulas of dithranol (1), chrysazine (2) and $1,8,1^{\prime}, 8^{\prime}-$ tetrahydroxybisanthrone (3)

focused laser beam (LAMMA [3]) indicated the presence of copper $(\mathrm{m} / \mathrm{z}=63$ and $\mathrm{m} / \mathrm{z}=65$; intensity relation approximately $2: 1$ ); under identical conditions, no copper was found in the surrounding lightcoloured area. The application of LAMMA to scales from psoriatic lesions which had been treated with dithranol revealed the presence of negative ions at $240 \mathrm{mu}$ (chrysazine) and $225 \mathrm{mu}$ [either (M-1) ${ }^{-}$of dithranol or a fragment ion of $1,8,1^{\prime}, 8^{\prime}$-tetrahydroxybisanthrone; bisbenzylic cleavage]. The validation of these results with dithranol, chrysazine and the bisanthrone indicated $\mathrm{m} / \mathrm{z}=225$ for dithranol, [(M-H) $\left.{ }^{-}\right]$ and for the bisanthrone (fragmentation of the bisbenzylic bond), while chrysazine produced $\mathrm{M}^{\cdot-}$ at $\mathrm{m} / \mathrm{z}=240$, followed by loss of $29 \mathrm{mu}\left(\mathrm{HCO}^{\circ}\right)$ to $\mathrm{m} / \mathrm{z}=211$ (Fig. 2) [6].

When we heated brown scales to $300^{\circ} \mathrm{C}$ in a TAS apparatus (DESAGA, Heidelberg, FRG), we obtained a yellow sublimate which contained chrysazine. Van Duuren et al. [8] have prepared complexes of chrysazine with various metals including copper. Although copper and chrysazine are found in the same compartment, the identity of Van Duuren's complex and dithranol brown cannot be deduced from 


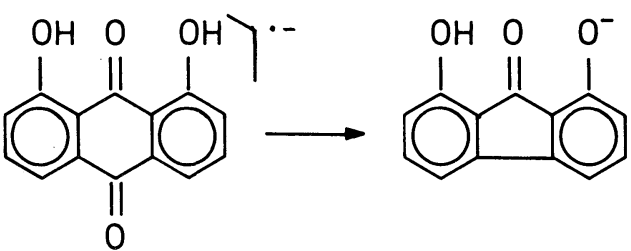

Fig. 2. LAMMA of chrysazine: loss of $\mathrm{HCO}$

Table 1. Penetration und metabolization of $1 \%$ dithranol in white soft paraffin in psoriatic patients in vivo. Separation of the skin by suction blister technique

\begin{tabular}{lclll}
\hline & $\begin{array}{l}\text { Penetration } \\
\text { time [min] }\end{array}$ & Epidermis & $\begin{array}{l}\text { Blister } \\
\text { fluid }\end{array}$ & Dermis \\
\hline $\begin{array}{l}\text { Psoriatic } \\
\text { lesion }\end{array}$ & 60 & $\begin{array}{l}1:+ \\
2:+++ \\
3:++\end{array}$ & $2:+$ & Negative \\
& & $2:+$ & $2:+$ & $2:+$ \\
$\begin{array}{l}\text { Uninvolved } \\
\text { skin }\end{array}$ & 285 & & & \\
\hline
\end{tabular}

this experiment. We were unable to isolate this complex or any similar copper complex from the brown scales; Van Duuren's statement about the solubility and ligand exchange of his complex explains this failure. Our results, however, pointed towards a metabolization of dithranol to chrysazine in the epidermis. This proved to be true: after being treated with dithranol in white soft paraffin, the epidermis and dermis of the involved and uninvolved skin of psoriatic patients were separated by suction blisters [4]. The epidermis, the blister fluid and the upper part of the dermis were analysed (Table 1).

Although Sa e Melo et al. [7] using gas chromatography mass spectrometry (GC-MS) after the topical application of dithranol to normal human skin did not detect dithranol or its metabolites as silylized derivatives in suction-blister fluid, our results indicate that chrysazine and 1,8,1', $8^{\prime}$-tetrahydroxybisanthrone occur in the blister tissues of psoriatic skin. Although unlikely, the contribution of melanin to the discolouration was considered, because tyrosinase (polyphenol oxidase) is a $\mathrm{Cu}$-protein. This consideration was experimentally cancelled: the hypomelanotic areas of vitiligo patients are stained by dithranol.

\section{Experiments}

\section{Isolation of Brown Particles from Scales}

Brown particles were excised out of brown scales using a micromanipulator under microscopic control. Brown particles $(0.1 \mathrm{mg})$ were extracted with DMSO in a Soxhlet apparatus, the solvent was evaporated in
Table 2. High resolution measurements

\begin{tabular}{llll}
\hline $\mathrm{m} / \mathrm{z}$ & Formula & Calculated & Found \\
\hline 252 & $\mathrm{C}_{18} \mathrm{H}_{36}$ & 252.28169 & 252.28118 \\
368 & $\mathrm{C}_{27} \mathrm{H}_{44}$ & 368.34429 & 368.34443 \\
386 & $\mathrm{C}_{28} \mathrm{H}_{50}(65 \%)$ & 386.39123 & 386.39013 \\
386 & $\mathrm{C}_{27} \mathrm{H}_{46} \mathrm{O}(35 \%)$ & 386.35485 & 386.35470
\end{tabular}

vacuo and the residue was analysed by mass spectrometry.

Brown scales $(15 \mathrm{mg})$ were degraded with $10 \mathrm{mg}$ Pronase (Boehringer) in $10 \mathrm{ml}$ Tris buffer for $2 \mathrm{~h}$ at $25^{\circ} \mathrm{C}$. The mixture was extracted three times with $10 \mathrm{ml} \mathrm{CHCl}_{3}$, and the organic solution was dried $\left(\mathrm{Na}_{2} \mathrm{SO}_{4}\right)$, evaporated in vacuo and analysed by thin layer chromatography (tlc) (Al sheets, silica $60 \mathrm{~F}_{254}$, toluene/glacial acetic acid $80 / 20 \mathrm{v} / \mathrm{v}$ ) and mass spectrometry. The high-resolution measurements $(311 \mathrm{~A})$ of the extract are given in Table 2.

\section{Electron-Impact (EI) Mass Spectrometry}

The mass spectra of dithranol, chrysazine and $1,8,1^{\prime}, 8^{\prime}$-tetrahydroxybisanthrone $(\mathrm{CH} 5)$ are as follows:

1. Dithranol: $12 \mathrm{eV}: \mathrm{m} / \mathrm{z}=226\left(\mathrm{M}^{+}, 100 \%\right)$; $70 \mathrm{eV}: \mathrm{m} / \mathrm{z}=226(100 \%), 198\left(\mathrm{M}^{+\cdot}-\mathrm{CO}, 22 \%\right), 181$ $(8 \%)$

2. Chrysazine: $12 \mathrm{eV}: \mathrm{m} / \mathrm{z}=240\left(\mathrm{M}^{+\cdot}, 100 \%\right)$; $70 \mathrm{eV}: \mathrm{m} / \mathrm{z}=240(100 \%), 212\left(\mathrm{M}^{+\cdot}-\mathrm{CO} ; 14 \% ; \mathrm{m}^{*}\right.$ $=187.27), 184\left(212-\mathrm{CO} ; 10 \%, \mathrm{~m}^{*}=159.70\right)$

3. $1,8,1^{\prime}, 8^{\prime}$-tetrahydroxybisanthrone: $11 \mathrm{eV}: \mathrm{m} / \mathrm{z}$ $=450\left(\mathrm{M}^{+},<1 \%\right), 225(100 \%) ; 70 \mathrm{eV}: \mathrm{m} / \mathrm{z}=225$ $(100 \%), 197(225-\mathrm{CO} ; 48 \%)$

\section{Laser Microprobe Mass Analyser (LAMMA) Experiments}

All measurements with $\lambda_{\text {Laser }}=265 \mathrm{~nm} ; \tau_{\text {Laser }}=10 \mathrm{~ns}$. The positive mass spectra of the brown particle revealed $\mathrm{m} / \mathrm{z}=63^{+}(\mathrm{Cu}, 100 \%)$ and $65^{+}(\mathrm{Cu}, 50 \%)$. The negative mass spectra of dithranol indicated $\mathrm{m} / \mathrm{z}=225\left[(\mathrm{M}-\mathrm{H})^{-}, 100 \%\right]$. One day after preparation, the pertinent spectra showed: $\mathrm{m} / \mathrm{z}=225$ $\left[(\mathrm{M}-\mathrm{H})^{-}, 100 \%\right], 240$ (chrysazine $\left.^{-}, 43 \%\right)$ and 211 $(5.5 \%)$. Under identical conditions, chrysazine led to fragments at: $\mathrm{m} / \mathrm{z}=240\left(\mathrm{M}^{-}, 100 \%\right)$ and 211 $\left[\left(\mathrm{M}-\mathrm{HCO}^{\circ}\right)^{-}, 80 \%\right]$ while $1,8,1^{\prime}, 8^{\prime}$-tetrahydroxybisanthrone was cleaved to $\mathrm{m} / \mathrm{z}=225\left(\mathrm{M} / 2^{-}, 100 \%\right)$.

\section{Preparation of the Chrysazine-Cu Complex}

This was performed according to the method of Van Duuren et al. [8]. 


\section{Pyrolysis of Brown Scales in a TAS Apparatus}

About $10 \mathrm{mg}$ brown scales were cut into pieces, placed in the glass tube of a TAS apparatus and heated to $150^{\circ}, 200^{\circ}, 250^{\circ}, 300^{\circ}$ and $350^{\circ} \mathrm{C}$.

\section{Analysis of Blister Tissue}

Highly refined $1 \%$ dithranol [1] in white soft paraffin was applied to both the uninvolved skin and lesions of psoriatic patients in vivo; after defined periods, it was removed by washing with a hydrophile lipogel (Table 1). The epidermis and dermis were separated using the suction-blister technique [4], and the tissue samples were stored at $-25^{\circ} \mathrm{C}$. Histologically identical samples were combined in batches of $2-30 \mathrm{mg}$ and extracted with $5 \mathrm{ml}$ acetone under $\mathrm{N}_{2}$ at room temperature. The solvent was evaporated in a $\mathrm{N}_{2}$ stream, and the residue was dissolved in $0.50 \mathrm{ml}$ acetone; $10 \mu \mathrm{l}$ of this solution were used for tlc.

Acknowledgements. We thank Mrs I. Segschneider and Mrs H. Feller for skillful technical assistance. The financial support of the Deutsche Forschungsgemeinschaft is gratefully acknowledged.

\section{References}

1. Auterhoff H, Scherff FC (1960) Die Dianthrone der pharmazeutisch interessierenden Hydroxyanthrachinone. Arch Pharm (Weinheim) 293:918-925

2. Brockmann H, Neef R, Mühlmann E (1950) Zur Synthese hypericin-ähnlicher Oxy-naphthodianthrone. Chem Ber 83: $467-484$

3. Hillenkamp $F$ (1983) Laser-induced ion formation from organic solids. Springer Ser Chem Phys 25:190-205

4. Kiistala U, Mustakallio KK (1964) In vivo separation of epidermis by production of suction blisters. Lancet $1: 1444-$ 1445

5. Runne U, Kunze J (1982) Short-duration (“minutes") therapy with dithranol for psoriasis: a new out-patient regimen. Br J Dermatol 106:135-139

6. Runne U, Rosmarinowski J, Safar GJ, Kupka KD, SchultzAmling W, Plumier E, Wiegrebe W (1983) Demonstration of dithranol in normal and psoriatic skin with laser-microprobe mass analysis (LAMMA) and biochemical techniques. Measurement methods for the in vivo penetration and metabolization. Arch Dermatol Res 275:269-270

7. Sa e Melo T, Dubertret L, Prognon P, Gond A, Mahuzier G, Sautus R (1983) Physiochemical properties and stability of anthralin in model systems and human skin. Invest Dermatol $80: 1-6$

8. Van Duuren BL, Segal A, Tseng S-S, Rusch GM, Loewengart UM, Roth D, Smith A, Melchionne S, Seidman J (1978) Structure and tumor-promoting activity of analogues of anthralin. J Med Chem $21: 26-31$

Received March 13, 1984 